\title{
PKU Bagi MI Muhamamdiyah Rambeanak 2 Kabupaten Magelang, Melalui Alat Peraga Edukatif (APE)
}

\author{
Ahwy Oktradiksa ${ }^{1}$, Minzani Aufa ${ }^{2}$ \\ ${ }^{1,2}$ Pendidikan Guru Madrasah Ibtidaiyah, Fakultas Agama Islam, Universitas Muhammadiyah \\ Magelang \\ 1'ahwy@ummgl.ac.id \\ ${ }^{2}$ minzaniaufa@ummgl.ac.id
}

\begin{abstract}
ABSTRAK
Madrasah Ibtidaiyah Muhamadiyah (MIM) 2 Rambeanak memiliki siswa sebanyak 127 orang, guru sebanyak 8 orang, dan didirikan sejak tahun 1947, meski sudah setengah abad didirikan, namun sampai saat ini masih mengalami sejumlah kendala, di antaranya adalah 1) kondisi obyektif dari guru dan sumber daya manusia dan sumber daya media pembelajaran berupa Alat Peraga Edukatif (APE) sehingga berdampak pada keterbatasan dalam mendukung proses pembelajaran berkualitas; 2) minimnya dukungan stakeholders madrasah dalam pengembangan madrasah baik secara moril maupun materiil. Sehubungan dengan hal tersebut, maka akan dilakukan kegiatan Program Kemitraan Universitas (PKU) yang bertujuan untuk peningkatan mutu madrasah menuju madrasah dengan proses pendidikan yang berkualitas melalui pendampingan pembuatan APE bagi guru. Metode yang digunakan pemberdayaan masyarakat partisipatif Participatory Rural Apraisal (PRA). Adapun kesimpulan yang dapat diberikan dalam pelaksanaan PKU di MIM 2 Rambeanak sebagai berikut : 1) Setelah dilakukan pendekatan melalui sosialisasi tentang pentingnya APE, maka guru bisa membuat dan berdampak pada gaya guru mengajar yang menarik dan hasil belajar siswa menjadi baik, 2) Setelah guru melakukan diseminasi hasil pembuatan APE, maka guru menjadi lebih kreatif dengan memanfaatkan bahan yang ekonomis dan tertarik untuk membuat lebih banyak lagi APE dengan ide yang brilian berdasarkan pengalaman yang sudah dilakukan selama kegiatan PKU berlangsung.
\end{abstract}

Kata kunci: $P K U, M I$ Muhammadiyah 2 Rambeanak, $A P E$

\section{ABSTRACT}

Madrasah Ibtidaiyah Muhamadiyah (MIM) 2 Rambeanak has 127 students, 8 teachers, and was founded in 1947, although it has been established for half a century, but to date there are still a number of obstacles, including 1) the objective conditions of the teacher and human resources and instructional media resources in the form of Educational Teaching Aids (APE) so that the impact on limitations in supporting the quality learning process; 2) the lack of support from madrasa stakeholders in madrasa development both morally and materially. In connection with this, the University Partnership Program (PKU) activity will be carried out which aims to improve the quality of madrasas towards madrasas with a quality education process through mentoring making APE for teachers. The method used is Participatory Rural Appraisal (PRA) participatory community empowerment. The conclusions that can be given in the implementation of PKU in MIM 2 Rambeanak are as follows: 1) After an approach through socialization about the importance of APE, the teacher can make and have an impact on the teacher's teaching style that is interesting and student learning outcomes become good, 2) After the teacher does the dissemination of the results of making APE, the teacher becomes more creative by utilizing economical materials and is interested in making more APE with brilliant ideas based on experience that has been done during PKU activities.

Keywords: PKU, MI Muhammadiyah 2 Rambeanak, APE

\section{PENDAHULUAN}

\subsection{Analisis Situasi}

Bermain adalah suatu perbuatan yang dilakukan oleh seorang anak untuk menyenangkan hati dengan menggunakan alat- alat tertentu maupun tidak. Dengan pola belajar sambil bermain dan pola bermain sebagaimana belajar anak merasa nyaman. Alasannya, tanpa sengaja, anak bermain sambil belajar dalam permainan dan bermain dalam belajar. Antara 
belajar dan bermain sama-sama menyenangkan sekaligus menantang. Kondisi belajar yang menyenangkan sekaligus menantang inilah yang mempunyai potensi besar membentuk karakter anak menjadi seorang pembelajar sejati. Hasil belajar anak meningkat tajam karena semakin banyak permainan yang dilakukannya semakin menambah tingkat kecerdasannya. Lebih dari itu, kelak di masa dewasa, bahkan hingga di masa tua, ia akan mempunyai hobi yang sangat mengagumkan, yakni belajar. Ia menikmati belajar sama dengan menikmati permainan. Semunya dirasakan sangat menyenangkan dan menantang, tetapi mencerdaskan. Perasaan ini yang mendorong anak untuk belajar setiap saat, tanpa disuruh dan diawasi.(Suyadi, 2009)

Meningkatkan mutu MI adalah menjadi kebutuhan yang harus dilakukan, yaitu dengan pemberdayaan madrasah (schools empowerment). Pemberdayaan yang dimaksud di sini adalah sistem pendidikan bermutu kepada masyarakat yang ditunjang oleh tiga apek, yaitu manajemen yang rapi, tenaga pendidik (guru) profesional, serta dana dan fasilitas pendidikan yang memadai. MI yang dikelola dengan tertib dan rapi akan memiliki kesempatan besar untuk menjadi sebuah lembaga pendidikan yang berkualitas dan dibutuhkan oleh masyarakat di era Revolusi Industri 4.0 yang begitu banyak di warnai oleh faham materialistik.(Oktradiksa, Sari, \& Shalikhah, 2017) Namun dalam kenyataannya, pengembangan mutu madrasah terkhusus MI Muhammadiyah Rambeanak 2 dihadapkan pada masalah yang fundamental seperti: 1) guru MI belum mempunyai Alat Peraga Edukatif (APE); 2) guru kurang kreatif dalam membuat APE sehingga berdampak pada metode pembelajaran menggunakan teknologi pembelajaran berbasis kearifan lokal.

APE adalah segala bentuk permainan yang dapat memberikan pengetahuan dan kemampuan anak. Alat Permainan Edukatif yang digunakan adalah alat untuk bermain anak. Indikator alat permainan disebut edukatif jika mampu mengembangkan aspek tertentu pada anak.(Suyadi, 2010)

APE adalah alat permainan yang dapat mengoptimalkan perkembangan anak sesuai usia dan tingkat perkembangannya dan yang berguna untuk pengembangan aspek fisik, bahasa, kognitif dan sosial anak.(Soetjiningsih, 2002) APE adalah alat permainan yang sengaja dirancang secara khusus untuk kepentingan pendidikan.(Suyadi, 2010) Mendifinisikan bahwa permainan edukatif berbasis media adalah aktivitas anak yang menggunakan benda, bahan ataupun instruksi dan teknik yang dapat merangsang anak untuk belajar. Keberhasilan belajar melalui permainan edukatif berbasis media ditentukan oleh seberapa banyak alat indra yang digunakan dalam bermain semakin berhasil belajar anak. APE berpendapat bahwa APE memiliki beberapa ciri yaitu: a) dapat dilakukan dalam beberapa cara, maksudnya alat permainan itu dapat dimainkan dengan bermacam-macam tujuan dan manfaat; b) ditujukan terutama untuk anakanak usia prasekolah dan berfungsi untuk mengembangkan berbagai aspek perkembangan kecerdasan serta motorik anak; c) membuat anak terlibat secara aktif karena dalam proses bermain anak akan menggunakan alat permainannya. Selain itu, anak juga bisa berinteraksi dengan mainan, teman dan guru selama proses bermain dengan menggunakan alat permainan; d) bersifat konstruktif yaitu cara bermain yang bersifat membangun, membina, memperbaiki, dimana anakanak menggunakan bahan untuk membuat sesuatu yang bukan untuk bertujuan bermanfaat, melainkan ditujukan bagi kegembiraan yang diperolehnya dari membuatnya.(Tedjasaputra, 2007)

\subsection{Masalah mitra}

Dari analisis situasi diatas dapat kita tarik kesimpulan bahwa pengembangan mutu madrasah melalui media pembelajaran APE dalam mendukung proses pembelajaran menjadi sebuah keniscayaan dan bahkan keharusan. Namun dalam pelaksanaanya muncul permasalahan yang dialami oleh mitra. Berikut disampaikan beberapa hal yang dikeluhkan oleh mitra :

a. Guru MI belum mempunyai Alat Peraga Edukatif (APE);

b. Guru kurang kreatif dalam membuat APE sehingga berdampak pada metode pembelajaran menggunakan teknologi pembelajaran berbasis kearifan lokal.

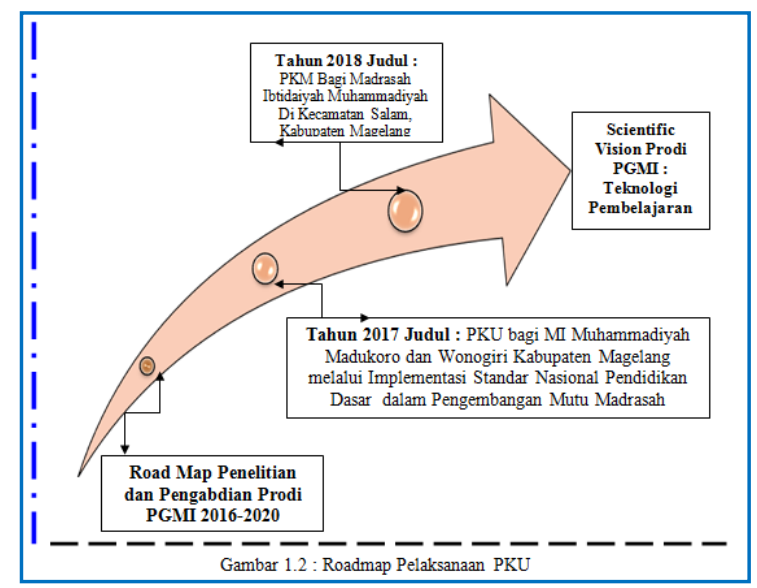




\section{METODE KEGIATAN}

Metode yang akan dipakai dalam kegiatan ini adalah model pemberdayaan masyarakat partisipatif yaitu Participatory Rural Apraisal (PRA). Metode PRA dipilih berdasarkan pertimbangan bahwa yang mempunyai atau menghadapi masalah adalah mitra, oleh karena itu keterlibatan mitra dalam penentuan pemecahan masalah dan penyelesaiannya sangat diperlukan. Metode tersebut dibagi menjadi 3 tahap yaitu persiapan, pelaksanaan, dan penyusunan laporan.(Afandy, 2014) Rinciannya sebagai berikut:

2.1. Tahap persiapan, meliputi :

a. Memberitahukan kegiatan melalui pimpinan cabang muhammadiyah kecamatan mungkid.

b. Menyiapkan teknologi yang akan diterapkan kepada sasaran mitra.

c. Menyusun jadwal kegiatan dan melakukan pembagian tugas di antara anggota tim sebagaimana berdasarkan kompetensi masing-masing.

2.2. Tahap pelaksanaan meliputi:

Kegiatan 1 : Sosialisasi dan diskusi tentang perencanaan pembuatan APE dan Aplikasi APE dalam pembelajaran.

Kegiatan 2

a. Pemetaan APE berdasarkan materi ajar dengan pengajuan proposal dari masingmasing guru MI.

b. Pendampingan implementasi APE dan ukur ketercapaian peningkatan kemapuan dan pengetahuan siswa dengan menggunakan APE.

c. Pembuatan katalog APE

2.3. Tahap Penyusunan Laporan :

a. Penyusunan laporan kemajuan, minimal 75 $\%$ selesai dalam waktu sesuai dengan jadwal yang telah ditentukan.

b. Penyusunan laporan akhir beserta seluruh instrument pelaporan dilakukan setelah seluruh kegiatan pengabdian pada masyarakat ini selesai.

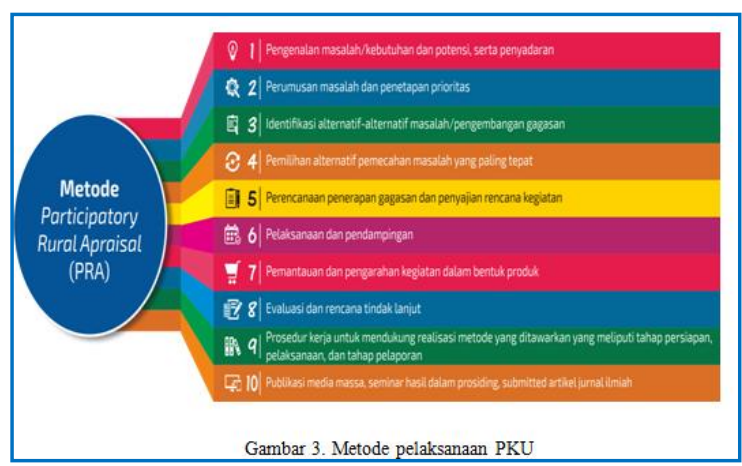

\section{HASIL \& PEMBAHASAN}

Program pengabdian ini dilaksanakan sebagai wujud pengembangan program Alata Peraga Fdukatif (APE) di MI Muhammadiyah Jumoyo dan MI Muhammadiyah Jagalan (2017) yang hasilnya sangat berdapak efektif pada hasil belajar siswa.(Oktradiksa, Sari, \& Nugroho, 2018) berdasarkan karakteristik siswa MI/SD yang masih terikat pada objek-objek konkret, dan anak mulai berpikir logis namun masih membutuhkan bantuan benda-benda konkret tersebut, maka diperlukan unutk mempermudah siswa memehami materi pekajran. Alat peraga adalah adalah alat bantu dalam pengajaran (dapat berupa benda hidup, benda mati atau benda media animasi) unutk meragakan sesuatu supaya apa yang diajarkan mudah dimengerti,(Istiani \& Arnidha, 2018) Media pembelajaran adalah alat yang dapat membantu proses belajar mengajar dan berfungsi untuk memperjelas makna pesan yang disampaikan, sehingga dapat mencapai tujuan pembelajaran dengan lebih baik dan sempurna.(Annisah, 2014) Kurang tersedianya sarana dan prasarana yaitu media pembelajaran yang bervariasi serta rendahnya pemahaman dan keterampilan guru untuk merancang media pembelajaran matematika yang inovatif berbanding terbalik dengan tuntutan implementasi Kurikulum 2013 dengan pendekatan saintifik yaitu adanya kemampuan siswa dalam visualisasi objek-objek matematika. Akibatnya siswa belajar matematika dengan cara-cara yang kurang bermakna. Siswa cenderung menghafal konsep atau prosedur matematis tertentu dan belajar matematika lebih banyak secara mekanistik. Hal ini berdampak pada rendahnya prestasi belajar matematika yang dicapai siswa. Ratarata hasil belajar siswa belum mencapai Kriteria Ketuntasan Minimal (KKM) yang ditetapkan oleh sekolah.(Taneo, Daniel, \& Bien, 2018)

\section{Program 1 : Forum Group Discussion}

Kegiatan awal yang dilakukan adalah, melakukan koordinasi dengan pihak MI Muhammadiyah 2 Rambeanak Kabupaten Magelang, dengan membawa surat tugas Lembaga Pengembagan Pendidikan dan Pengabdian Pada Masyarakat (LP3M) Universitas Muhamamdiyah Megalang dengan skim Program Kemitraan Universitas (PKU). Pada pelaksanaannya sesuai metode yang kami gunakan dalam program kemitraan ini adalah Participatory Rural Apraisal (PRA) dengan melibatkan semua guru MI Muhammadiyah 2 Rambeanak dengan komitmen warga madrasah 
untuk mewujudkan pembelajaran di madrasah yang berkualitas. Kegiatan ini dilaksanakan di MI Muhammadiyah Jagalan, hari selasa, tanggal 13 Februari 2019, Jam 13.00-15.00 WIB. tujuan kegiatan ini adalah untuk memberikan pemahaman tentang persiapan, perencanaan, dan evaluasi apa yang menjadi target luaran dari PKU.

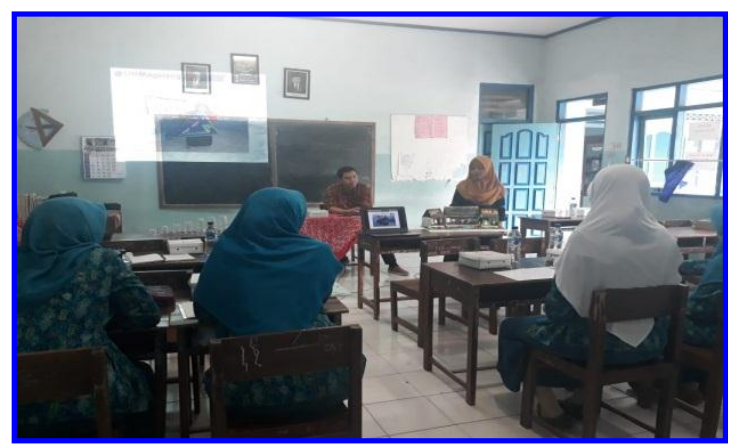

(Gambar 1. Forum Group Discussion)

\section{Program 2 : Pendampingan Pembuatan} APE

Pedampingan pembuatan APE dilakukan setiap minggu dilaksanakan pada hari sabtu dengan tujuan pembuatan APE bisa mengahdilkan produk dan luaran yang bagus sehingga dampatnya bisa digunakan untuk jangka panjang dan berkelanjutan. Kegiatan ini berlangsung pada hari sabtu, tanggal 16, 23, Februari dan 2 Maret 2019, jam 12.30-14.00, dengan jumlah peserta 8 orang Guru MI Muhammadiyah 2 Rambeanak.

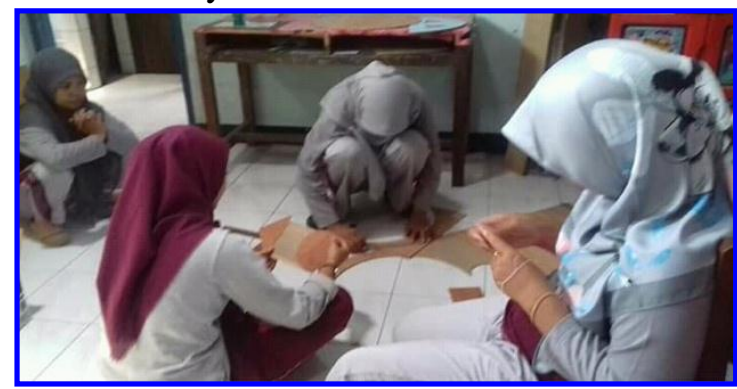

(Gambar 2. Proses pembuatan APE tahap 1 oleh guru MI Muhammadiyah 2 Rambeanak)

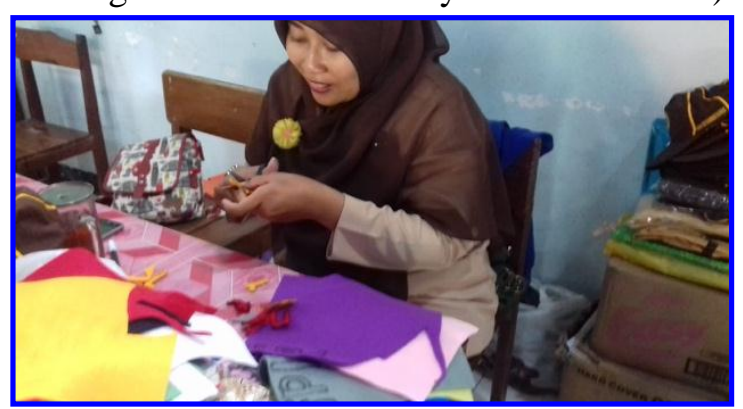

(Gambar 3. Proses pembuatan APE tahap 2 oleh guru MI Muhammadiyah 2 Rambeanak)

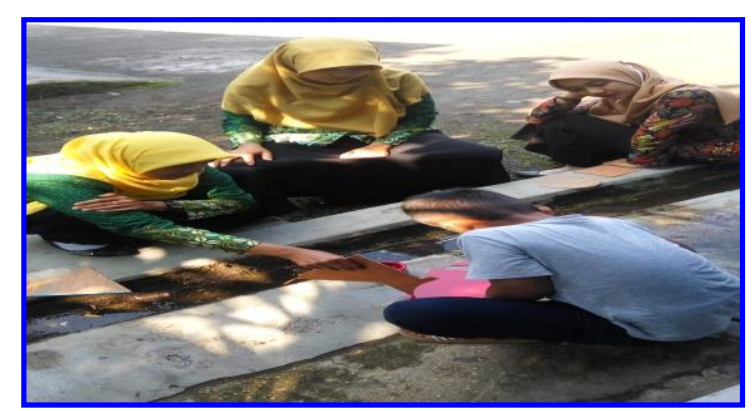

(Gambar 4. Proses pembuatan APE tahap 3 oleh guru dan siswa MI Muhammadiyah 2

Rambeanak)

\section{Program 3 : Diseminasi Hasil APE}

Program diseminasi APE dilakukan untuk menguji dan memberikan masukan mengenai APE yang dibuat, sehingga dapat memberikan dampak yang besar untuk kesempurnaan APE yang sudah dibuat oleh guru MI Muhammadiyah 2 Rambeanak. Kegiatan ini dilaksanakan pada hari rabu, tanggal 6 Maret 2019, jam 11.30-14.00 WIB.

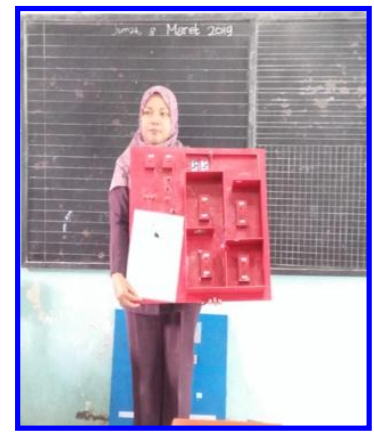

Gambar 5. Perangpari (Peraga Rangkaian Paralel dan Seri)

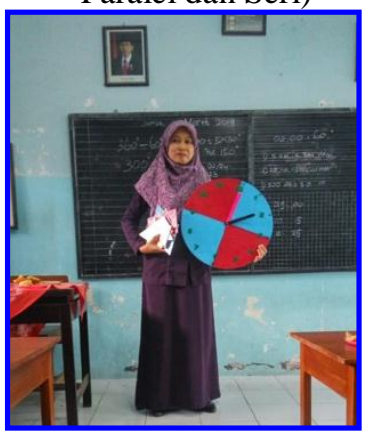

Gambar 7. Bersujam (Bermain Sudut Jam

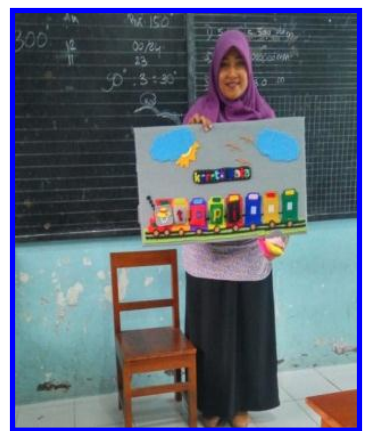

Gambar 6. Kereta Kata

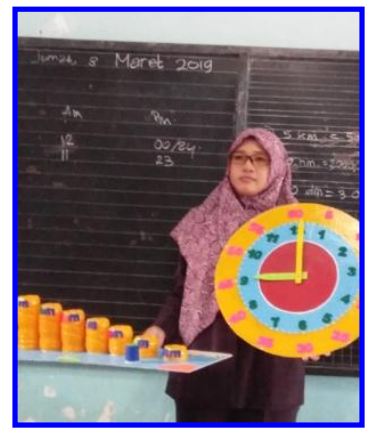

Gambar 8. Tasakur (Tangga Satuan Ukur) dan Aperjamen (Alat Peraga Jam dan Menit) 


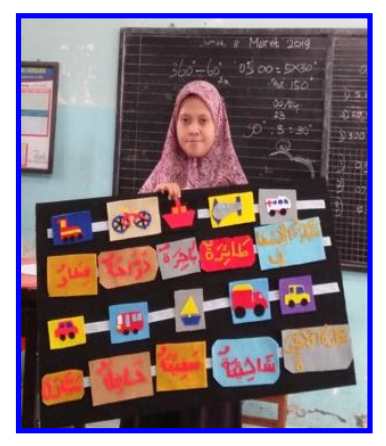

Gambar 9. Kedaba
(Kendaraan dalam
bahasa Arab)

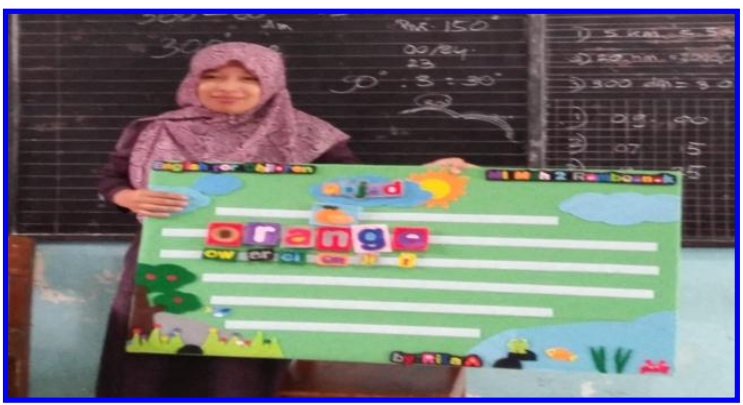

(Gambar 11. English for Children)

\section{KESIMPULAN \& SARAN}

Adapun kesimpulan yang dapat diberikan dalam pelaksanaan Progam Kemitraan Universitas (PKU) di MI Muhammadiyah 2 Rambeanak sebagai berikut :

1. Setelah dilakukan pendekatan melalui sosialisasi tentang pentingnya APE (Alat Peraga Edukatif), maka guru bisa membuat alat tersebut guna membantu proses penyampaian materi ajar dengan baik sehinga berdampak pada gaya mengajar bagi guru dan hasil belajar siswa menjadi menarik sehingga berefek pada hasil nilai siswa menjadi baik.

2. Setelah guru melakukan diseminasi hasil pembuatan APE, maka guru menjadi lebih kreatif dengan memanfaatkan bahan yang ekonomis dan tertarik untuk membuat lebih banyak lagi APE dengan ide yang brilian berdasarkan pengalaman yang sudah dilakukan selama kegiatan PKU berlangsung.

Adapun saran yang dapat diberikan :

1. Pembuatan APE dalam PKU UMMagelang dilaksanakan sebagai sarana media untuk mempermudah komunikasi pembelajaran antar siswa dan guru, maka hendaknya untuk selalu saling melengkapi dalam ide sehingga dampak pembuatan bisa digunakan untuk semua jenjang kelas rendah dan tinggi sesuia materi yang akan disajikan.

\section{DAFTAR PUSTAKA}

Afandy, A. (2014). Modul Participatory Action Research (PAR), Untuk Pengorganisasian Masyarakat (Community Organizing. Surabaya: Lembaga Penelitian dan Pengabdian Kepada Masyarakat (LPPM) UIN Sunan Ampel.

Annisah, S. (2014). Alat Peraga Pembelajaran Matematika. 11, 1-15.

Istiani, A., \& Arnidha, Y. (2018). Pendampingan Pembuatan dan Penggunaan Alat Peraga Dakota Pada Pembelajaran FPB dan KPK. Publikasi Pendidikan, $8(1), \quad 66$. https://doi.org/10.26858/publikan.v8i1.47 54

Oktradiksa, A., Sari, K. P., \& Nugroho, I. (2018). PKM Bagi Madrasah Ibtidaiyah Muhammadiyah Di Kecamatan Salam Kabupaten Magelang. Publikasi Pendidikan, 8(3), 193. https://doi.org/10.26858/publikan.v8i3.64 24

Oktradiksa, A., Sari, K. P., \& Shalikhah, N. D. (2017). PKU Bagi MI Muhammadiyah Madukoro dan Wonogiri Kabupaten Magelang Melalui Implementasi Standar Nasional Pendidikan Dasar Dalam Pengembangan Mutu Madrasah. 53-58.

Soetjiningsih. (2002). Tumbuh Kembang Anak. Cetakan II. Jakarta: EGC.

Suyadi. (2009). Permainan Edukatif yang Mencerdaskan. Yogyakarta: Power Books (IHDINA).

Suyadi. (2010). Psikologi Belajar Pendidikan Anak Usia Dini. Yogyakarta: Pustaka Insani Madani.

Taneo, P. N. L., Daniel, F., \& Bien, Y. I. (2018). Pendampingan Pembuatan dan Penerapan Alat Peraga Matematika bagi Guru SD Gugus II Kecamatan Amanuban Barat. Publikasi Pendidikan, 8(3), 229. https://doi.org/10.26858/publikan.v8i3.68 05

Tedjasaputra, M. S. (2007). Bermain, Mainan dan Permainan. Cetakan IV. Jakarta: PT Gramedia Widiasarana Indonesia. 